IZA DP No. 7612

The Impact of Incumbency on Turnout: Evidence from Italian Municipalities

Marco Alberto De Benedetto Maria De Paola

September 2013 


\title{
The Impact of Incumbency on Turnout: Evidence from Italian Municipalities
}

\author{
Marco Alberto De Benedetto \\ Birkbeck, University of London \\ Maria De Paola \\ University of Calabria \\ and IZA
}
Discussion Paper No. 7612
September 2013

\author{
IZA \\ P.O. Box 7240 \\ 53072 Bonn \\ Germany \\ Phone: +49-228-3894-0 \\ Fax: +49-228-3894-180 \\ E-mail: iza@iza.org
}

Any opinions expressed here are those of the author(s) and not those of IZA. Research published in this series may include views on policy, but the institute itself takes no institutional policy positions. The IZA research network is committed to the IZA Guiding Principles of Research Integrity.

The Institute for the Study of Labor (IZA) in Bonn is a local and virtual international research center and a place of communication between science, politics and business. IZA is an independent nonprofit organization supported by Deutsche Post Foundation. The center is associated with the University of Bonn and offers a stimulating research environment through its international network, workshops and conferences, data service, project support, research visits and doctoral program. IZA engages in (i) original and internationally competitive research in all fields of labor economics, (ii) development of policy concepts, and (iii) dissemination of research results and concepts to the interested public.

IZA Discussion Papers often represent preliminary work and are circulated to encourage discussion. Citation of such a paper should account for its provisional character. A revised version may be available directly from the author. 
IZA Discussion Paper No. 7612

September 2013

\section{ABSTRACT}

\section{The Impact of Incumbency on Turnout: Evidence from Italian Municipalities}

We analyze how having an incumbent among candidates affects electoral turnout. We use a rich data set providing information on the electoral results of Italian municipal elections over the period 1993-2011. Endogeneity issues are handled through an instrumental variable approach using the mayor term-limit as an instrument for the presence of the incumbent mayor among candidates. Controlling for electoral competition, we find that the impact of incumbency is heterogeneous across geographical areas: incumbency increases turnout in the South of Italy, whereas we do not find any statistically significant effect in the North. As the positive effect holds true only for southern municipalities endowed with low levels of social capital we speculate that this is the result of incumbent politicians using their resources to establish clienteles.

JEL Classification: D72, D78, J71, J16

Keywords: incumbency, political participation, electoral turnout, social capital

Corresponding author:

Maria De Paola

Department of Economics and Statistics

University of Calabria

87036, Arcavacata di Rende (CS)

Italy

E-mail:m.depaola@unical.it

\footnotetext{
* We would like to thank Alessandra Antonelli, Francesca Gioia and Vincenzo Scoppa for useful comments and suggestions.
} 


\section{Introduction}

While a large literature has investigated the effect of the incumbency status on the probability that an incumbent candidate wins the electoral competition, little is known on how incumbency affects turnout.

Having an incumbent among candidates at the electoral race could affect turnout through a number of channels. Firstly, the incumbent candidate, due to the so-called incumbency advantage (disadvantage), can reduce (increase) the degree of political competition and, as a consequence, voters might be less (more) inclined to participate to the polls. This would be an indirect effect, since the electoral turnout is influenced through the change that the presence of an incumbent produces on electoral competition. Electoral turnout may also be influenced through more direct channels. First of all, maintaining constant the level of political competition, elections in which one or more incumbents run for re-election are typically characterized by a higher availability of information, since citizens had the opportunity to observe, even if imperfectly, past performance of incumbent candidates. The increase in the availability of information on candidates' expected performance can lead to ambiguous effects on turnout. On the one hand, if the incumbent has been a good politician in the past, voters may want to support him/her and cast their vote. On the other hand, if he/she has poorly performed in the past, citizens may either decide to cast their vote in favor of a new candidate in order to punish the incumbent, leading to an increase in turnout, or they may not have any incentive to go to the polls, leading to a lower turnout (Grofman et al., 1995; Keele, 2007). An additional direct channel through which incumbency can affect turnout is related to the fact that incumbent politicians are able to use their power and resources to obtain "exchange votes" leading, by this way, to an increase in political participation. This type of relationship based on the log-rolling usually characterizes the poorest areas of a country and could be stronger in the presence of an incumbent running for re-election.

In this paper we try to shed some light on these effects. We analyze the relationship between incumbency and turnout using a rich data set providing information on the results of the Italian municipal elections over the period 1993-2011. To handle problems deriving from the fact that the incumbent's decision to run for election is endogenous and may be affected by unobservable and time variant variables that also affect turnout (for instance some unobservable skills of the incumbent may affect his her decision to run for election and voters' decision to cast their vote), we implement an instrumental variable strategy. We use as an instrument for the presence of an incumbent among candidates the mayor term-limit imposed by the Italian law. According to this law (DL 25 March 1993, no. 81), if the outgoing mayor has already been confirmed for two consecutive terms, he/she cannot run at the next election. Two-StageLeast-Square results show a negative and statistically significant effect of having an incumbent among candidates on turnout. However, this effect is mainly driven by the negative effect that the incumbent candidate produces on electoral competition. Once we control for the degree of competition characterizing the electoral race, the negative effect persists (even if it is not statistical significant) only for municipalities 
located in the North of Italy, whereas for elections held in the Center-South the effect is positive and statistically significant.

This heterogeneous effect points to the differences in the economic and social conditions of the two geographical areas. As the southern part of the country is poorer and endowed with a low level of social capital, the positive impact of incumbency on turnout may be related to the clientelistic relationships established by the incumbent candidates, which ensure political support in exchange of benefits ("exchange votes"). Areas endowed with low social capital are characterized by relationships that often involve requests for jobs and patronage and citizens living in these areas may be more inclined to cast their vote in relation to exchange agreements (Knack, 2002). This is more likely to happen in elections in which the incumbent runs for re-election since helshe had the opportunity to divert public resources to gain votes.

To investigate this issue we have analyzed the effect of incumbency in relationship to the social capital. The main difference in social capital endowment in Italy is between North and South. However, there are also differences within each area. Then, we consider variation in social capital within each geographical area. We find that the positive relationship between turnout and incumbency holds true only in southern municipalities characterized by low levels of social capital.

Our work is related to the literature investigating the determinants of turnout and more in particular to a strand of the literature analyzing the impact of candidates' characteristics on political participation. The idea at the basis of these works is that information on candidates' characteristics allows voters to make inference on candidates' skills. For instance, McDermott (2005), by focusing on statewide elections held in California, studies the impact of the candidate occupational label on voters' choice. She shows that candidate occupational clue helps voters to make a decision in low-information races, reducing abstention. On the same vein, Kahn (1993) shows that information on past political experience leads to an increase in electoral participation, since voters by getting these information realize that candidates have already developed some specific abilities in the political sector.

Other similar papers have investigated how turnout is affected by the presence of female candidates on turnout (De Paola et al. 2013; Wolf 2011; McDermott, 1997) ${ }^{1}$ and by candidates' race (Sigelman et al., 1995, Washington, 2006) ${ }^{2}$. In fact, voters could obtain utility from voting for candidates of their own gender/race or they may consider gender/race as a proxy for candidates' quality and preferences. Similar

\footnotetext{
${ }^{1}$ De Paola et al. (2013), relying on the exogenous variation in the number of female candidates induced by the introduction of gender quotas in Italy, find a positive effect on turnout. McDermott (1997), focusing on US, shows a positive impact on liberal electors while the effect on conservative electors is negative. Further, Wolf (2011) does not find any statistically significant effect.

${ }^{2}$ Sigelman et al. (1995) conduct an experiment in which they study the effect of being a white elector, self-identified as political liberal, moderate, or conservative, on the probability of voting for a Black or White U.S. Senate candidate who was quoted as voicing either liberal, moderate, or conservative positions. Results show that voters are influenced by the candidate's racial-ethnic identity primarily to the extent that they assume that moderate or conservative minority candidates would be more compassionate toward the disadvantaged. Washington (2006), focusing on contests for the United States House of Representatives, finds that black voter turnout increases by 2.3 percentage points for every Black Democrat on the ballot, while white voter turnout increases by 2.2 percentage points. The increased turnout is essentially explained by the perception of an extreme liberalness on the part of black candidates.
} 
channels may induce voters to change their behavior in relation to candidate sexual orientation (Golebiowska, 2001). ${ }^{3}$

Our work is also related to the very large literature investigating the incumbency advantage/disadvantage. In particular, De Paola et al. (2010), using the same data we consider in this paper, ${ }^{4}$ show that the percentage of votes obtained by each candidate and the probability of being elected as a mayor at Italian municipal elections is positively affected by incumbency. An incumbency advantage emerges also for US (Butler, 2009; Ansolabehere et al. 2000), and German federal elections (Hainmueller and Kern, 2008). Conversely, Titiunik (2009), analyzing the incumbency effect for Brazilian municipal elections, finds a negative impact. Similar results are found by Linden (2004) and Uppal (2009) for Indian elections and by Miguel and Zahidi (2004) for Ghana.

Some recent works have also considered how the incumbency advantage/disadvantage changes in relationship to exogenous changes in turnout, (see Hansford and Gomez, 2010; Trounstine, 2013), showing that higher turnout lowers the vote share for the candidate of the incumbent's party. In our paper we take a different perspective and look at the effect that an exogenous change in the probability of having an incumbent among candidates produces on turnout.

We also contribute to the literature analyzing the relationship between political accountability and social capital. Ferejohn (1986), Persson and Tabellini (2000), Alesina and Tabellini (2008), Besley (2005) show that social capital can affect political outcomes through two channels. First, higher social capital might induce individuals to bear the cost of gathering and processing information about the behavior of their political representative, putting them in the condition to punish misbehavior. Second, social capital may play a role in inducing voters to refrain from rewarding corrupt or lazy politicians despite receiving some targeted or clientelistic benefits and induce them to vote according to aggregate social welfare criteria. Some evidence on these effects is provided by Nannicini et al. (2013) that, using Italian data on the Italian members of Parliament, show how the electoral punishment of political misbehavior is considerably larger in electoral districts with high social capital. In line with this finding, we show that when social capital is low, voters are also less inclined to punish incumbent politician through abstention.

The paper is organized as follows. Section 2 is devoted to the description of the institutional framework and of our data set. In Section 3, we discuss municipal fixed effects estimates, whereas in Section 4 we present Two Stage Least Square results. Section 5 concludes.

\footnotetext{
${ }^{3}$ Golebiowska (2001), by drawing on two experimental investigations and using highly realistic audio-visual vignettes of ostensible candidates for office, explores how voters' responses to politically identical gay and lesbian candidates differ depending on whether their attributes are consistent or inconsistent with their respective group's stereotypes. Generally speaking, female voters evinced a preference for the masculine candidate, while male voters were less willing to vote for the stereotype-consistent candidate.

${ }^{4}$ More precisely, they use data on Italian municipal elections for the period 1993-2006.
} 


\section{Institutional Setting and Data}

In Italy, municipal administrations are involved in a number of important functions, such as the management of public utilities (local roads, water, sewage and garbage collection), the provision of public housing, transportation and nursery schools, and the assistance of elderly people. Since these services have a great impact on citizens' daily lives, voters are generally very interested in the composition and in the performance of Municipal Councils as well as in participating at elections.

The system currently regulating municipal elections in Italy has been introduced in 1993 (DL 25 March 1993, no. 81). It has established the direct election of the mayor and the adoption of the plurality rule, with some differences according to the size of the city. For municipalities with a population of fewer than 15,000 inhabitants, elections are held with single ballot and plurality rule: the winning candidate is awarded a majority premium of at least two-thirds of the seats in the council. For cities with a population above 15,000, elections are held using a dual ballot system (where the second ballot is held only if none of the candidates obtains an absolute majority of votes in the first ballot). Only the two leading candidates at the first round compete in the second ballot and the winning candidate is awarded a majority premium of at least 60 percent of the seats in the council.

Since 1993, mayors have been subject to a two-term limit, while members of the Executive Committee and of the Municipal Council, endowed with legislative power, can be re-elected indefinitely.

Municipal elections in Italy are held every 5 years ${ }^{5}$ and Municipal governments cannot choose the election schedule. In certain circumstances, the legislature may not survive until the end of its legislative term, e.g. because of a mayor's early resignation. In these cases, elections are held before the natural schedule, and, as a consequence, all subsequent elections will be held at different times from other municipalities that have completed the foreseen legislative term.

Municipalities have a registry of eligible voters, which is revised whenever there is an election and all citizens aged 18 or above on the election date are automatically registered to vote. Voting takes place in polling stations organized by the local authorities. Elections are organized according to a traditional paper ballot system.

Our empirical analysis is based on a panel data set, provided by the Italian Ministry of the Internal Affairs. In order to focus on elections regulated by the same rules, we only consider municipalities with less than 15,000 inhabitants, in which elections are held with single ballot and plurality rule. ${ }^{6}$ We end up with a sample composed by 22,629 observations for 6,499 Italian municipalities over the period 19932011. For each municipal election we have information on the number of voters and the number of people eligible to vote. We measure Turnout as the ratio between the number of voters and the number of eligible voters. As shown in Table 1, in which are reported some descriptive statistics, Italy is characterized by a

\footnotetext{
${ }^{5}$ With the exception of the years between 1993 and 1999, when the electoral mandate had a duration of 4 years.

${ }^{6}$ The results reported in this paper remain substantially unchanged if we include in our sample also municipalities voting under the dual ballot system (those with more than 15,000 inhabitants). Results are available upon request.
} 
quite high electoral turnout compared to many European countries and to US: the average turnout in the period 1993-2011 has been of 79.2\%, with a standard deviation of 0.092 .

We also have information on the number of candidates who run for a mayor position at each election, on their gender, age, educational attainment and previous job (Anagrafe degli Amministratori Locali, Ministero dell'Interno). ${ }^{7}$ Using this information, we build a dummy variable Incumbent taking the value of 1 when among the candidates running for election there is the exiting mayor and zero otherwise. From Table 1, we can notice that in $36 \%$ of elections there is, among candidates running for the mayor position, a candidate that has already performed this charge in the previous legislature.

According to the Italian law not all the incumbent mayors can run for election. Because of a term limit, mayors cannot spend more than two consecutive terms in office. Then, we define Binding Term Limit as a dummy variable equal to one if the term limit constraint is binding and equal to zero if the term limit is slack. In $19 \%$ of the elections, the term limit was binding and it was not possible to have the incumbent mayor among candidates.

Using the information on candidates' gender we have build a dummy variable Female Candidate taking the value of 1 when there is at least a female candidate running for a mayor position. The proportion of elections in which there is at least a woman participating at the electoral competition is about $20 \%$ with a standard deviation of 0.40 . Finally, the average Educational Attainment of candidates is quite high (14 years of education), highlighting how the majority of candidates has at least obtained a high-school diploma. ${ }^{8}$

Table 1: Descriptive Statistics

\begin{tabular}{|c|c|c|c|c|c|}
\hline Variables & Mean & Std. Dev. & Min & Max & $\begin{array}{c}\text { Observations } \\
9\end{array}$ \\
\hline Turnout & 0.792 & 0.092 & 0.0001 & 0.929 & 22,629 \\
\hline Incumbent & 0.360 & 0.480 & 0 & 1 & 22,629 \\
\hline Binding Term Limit & 0.190 & 0.392 & 0 & 1 & 22,629 \\
\hline Candidates’ Education & 14.097 & 2.879 & 5 & 18 & 22,629 \\
\hline Candidates’ Age & 47.778 & 7.976 & 19 & 84 & 22,629 \\
\hline Female Candidate & 0.204 & 0.403 & 0 & 1 & 22,629 \\
\hline Education of Population & 6.940 & 0.841 & 0.442 & 12.56 & 22,629 \\
\hline Population Size/1,000 & 3,379 & 3.213 & 0.033 & 14,966 & 22,629 \\
\hline Employment/Population & 0.240 & 0.136 & 0.006 & 0.846 & 22,629 \\
\hline \% Elderly People & 0.203 & 0.067 & 0.043 & 0.643 & 22,629 \\
\hline Electoral Margin & 0.204 & 0.220 & 0 & 0.875 & 22,629 \\
\hline No. of Candidates & 2.552 & 0.938 & 1 & 9 & 22,629 \\
\hline North & 0.54 & 0.489 & 0 & 1 & 22,629 \\
\hline South & 0.24 & 0.433 & 0 & 1 & 22,629 \\
\hline Center & 0.14 & 0.345 & 0 & 1 & 22,629 \\
\hline Isles & 0.08 & 0.269 & 0 & 1 & 22,629 \\
\hline
\end{tabular}

Source: Local Administrators Data set (1985-2011), Italian Ministry of Internal Affairs; Italian Census of Population (1991 and 2001).

\footnotetext{
${ }^{7}$ It is possible to obtain detailed data at an individual level at the following website: http://amministratori.interno.it

${ }^{8}$ In Italy, it takes 13 years to attain a High-School Degree while 17-18 years are necessary to attain a College Degree. Moreover, the educational attainment of people with a $\mathrm{PhD}$ or a Master degree is always 18 years in our sample.

${ }^{9}$ The number of observations refers to the regression in which we control for the political competition, as measured by the difference in votes (\%) between the winner and his/her closest challenger.
} 
Our data set allows us also to use some proxies of the degree of competition characterizing each electoral race. We have information on the number of votes obtained by each candidate and we create a variable Electoral Margin as the absolute difference between the number of votes obtained by the two leading candidates (divided by the number of eligible voters). Electoral Margin represents an inverse measure of expected electoral closeness and is on average equal to 0.204 , with a maximum of 0.875 and a minimum of $0 .{ }^{10}$ We also have information on the number of candidates running for the mayor position at each election which can also be considered a proxy for political competition. This variable has a mean value of 2.5 .

To control for municipalities’ demographic characteristics, we use the 1991 and 2001 Italian Census of Population. Data form the 1991 census are used for elections held in the period 1993-1996, while data from the 2001 census are used for elections held after 1996. We have information on the size of resident population, the average level of employment, the educational attainment of the population and the percentage of people aged 65 or over. As shown in Table 1, the average population size is 3,379, the average educational attainment of population, by considering only people aged 6 or above, is about 7 years. Further, the fraction of employed people in the population is $24 \%$, the proportion of elderly people in the population is on average about $20 \%$. Roughly $43 \%$ of municipalities are located in the South and Islands.

\section{Incumbency Status and Voter Turnout: Municipal Fixed Effects Estimates}

In this Section, we estimate a OLS model with fixed effects at municipal level to analyze whether having an incumbent mayor among candidates affects electoral participation. More precisely, we estimate the following model:

[1] Voter_Turnout $_{i t}=\beta_{0}+\beta_{1}$ Incumbent $_{i t}+\beta_{2}$ Political Competition $_{i t}+\beta_{3} X_{i t}+\beta_{4} Z_{i t}+\varphi_{i}+\mu_{t}+\varepsilon_{i t}$

where Voter_Turnout ${ }_{i t}$ is a variable measuring the electoral turnout (number of voters on number of eligible electors) in municipality $i$ in election year $t$; Incumbent $_{i t}$ is the variable of our main interest and it takes a value equal to 1 if the mayor in the previous legislature is among candidates and zero otherwise; Political Competition $_{\text {it }}$ is a vector containing both the degree of political competition as measured by the difference in votes (\%) between the winner and his/her closest challenger and the number of candidates at the electoral race; $X_{i t}$ is a vector of municipal characteristics at the time of elections, such as the population size, the population size squared, the average number of years of education of the inhabitants, the fraction of employed people in the population, the fraction of elderly people; $Z_{i t}$ is a

\footnotetext{
${ }^{10}$ The value of zero characterizes few elections in which the two candidates obtained exactly the same number of votes.
} 
vector of candidates' characteristics, such as the average age and education of candidates and a dummy variable taking the value of 1 when there is at least a woman among candidates; $\varphi_{i}$ and $\mu_{t}$ are respectively a municipal and an electoral year fixed effect, whereas $\varepsilon_{i t}$ is the stochastic error term of the model. The fixed effects $\varphi_{i}$ accounts for time-invariant characteristics of the municipality, either observable or unobservable.

In all regressions standard errors are robust to heteroskedasticity and are clustered at the municipal level to take into account the fact that the voters' behavior in the same municipality may be affected by common shocks.

In Table 2 we report estimates obtained when controlling for municipal fixed effects. In all specifications the dependent variable is voter turnout.

In column (1), we control only for demographic characteristics, and we find a negative and statistically significant, at 10 percent level, correlation between incumbency and turnout. In particular, having a candidate who performed the mayor charge in the previous legislature decreases the electoral participation by 0.001 percentage points.

In column (2) we add some candidates' characteristics as control variables. Again we find a negative and statistically significant correlation between incumbency and turnout.

In order to understand what drives this negative relationship, in column (3) and (4), we include among controls our measures of electoral competition. Both the electoral margin (see column (3)) and the number of candidates competing in the electoral race (see column (4)) produce the expected results: turnout is higher in closer elections and when the number of candidates is higher. ${ }^{11}$ Once we control for these variables, the effect of Incumbent ${ }_{i t}$ changes sign and becomes positive and statistically significant at the 1 percent level in both specifications, suggesting that, keeping constant the level of electoral competition, having an incumbent among candidates induces a higher number of electors to cast their vote.

As far as our control variables (municipal and candidates' characteristics) are concerned, we find the expected results. Voter turnout increases with the educational attainment of the population, while it decreases with population size, ${ }^{12}$ the employment rate and the percentage of elderly people. Candidates' characteristics also matter. Having more educated candidates running for the mayor position positively affects turnout, suggesting that electors decide to go to the polls and to cast their vote when candidates are considered qualified on the basis of their educational attainment. Further, having elderly candidates also positively affects turnout, maybe because older candidates are perceived as more experienced. On the other hand, having at least a female among candidates does not produce any statistically significant impact on turnout.

\footnotetext{
${ }^{11}$ These results are consistent with those found by Fauvelle-Aymar and Francois (2008) for French elections, by Simonovits (2011) for Hungarian elections and by De Paola and Scoppa (2011; 2012) for Italian municipal elections.

${ }^{12}$ This finding is in line with the idea that the single rational elector is not able to modify the electoral outcome alone and in turn, when population size increases, the expected utility deriving from casting the vote decreases, leading to voters' absenteeism (see for example Mueller, 2003).
} 
Table 2: Municipal fixed effects estimates. Incumbency and Voter Turnout

\begin{tabular}{|c|c|c|c|c|}
\hline VARIABLES & $\begin{array}{c}\text { (1) } \\
\text { Voter Turnout } \\
\text { Population } \\
\text { Controls }\end{array}$ & $\begin{array}{c}\text { (2) } \\
\text { Voter Turnout } \\
\text { Population and } \\
\text { Candidates' Controls }\end{array}$ & $\begin{array}{c}\text { (3) } \\
\text { Voter Turnout } \\
\text { Political Controls: } \\
\text { Electoral Margin }\end{array}$ & $\begin{array}{c}\text { (4) } \\
\text { Voter Turnout } \\
\text { Political Controls: } \\
\text { Electoral Margin and } \\
\text { Num. of Candidates } \\
\end{array}$ \\
\hline Incumbent & $\begin{array}{c}-0.0011^{*} \\
(0.0006)\end{array}$ & $\begin{array}{c}-0.0013 * * \\
(0.0006)\end{array}$ & $\begin{array}{c}0.0018 * * * \\
(0.0005)\end{array}$ & $\begin{array}{c}0.0018^{* * *} \\
(0.0005)\end{array}$ \\
\hline Population Size/1,000 & $\begin{array}{c}-0.0163^{* * *} \\
(0.0044)\end{array}$ & $\begin{array}{c}-0.0166 * * * \\
(0.0044)\end{array}$ & $\begin{array}{c}-0.0184 * * * \\
(0.0042)\end{array}$ & $\begin{array}{c}-0.0186 * * * \\
(0.0042)\end{array}$ \\
\hline Population Size^2 & $\begin{array}{c}0.0004^{* *} \\
(0.0002)\end{array}$ & $\begin{array}{c}0.0004^{* *} \\
(0.0002)\end{array}$ & $\begin{array}{c}0.0006 * * * \\
(0.0002)\end{array}$ & $\begin{array}{c}0.0006 * * * \\
(0.0002)\end{array}$ \\
\hline Education of Population & $\begin{array}{c}0.0135 * * * \\
(0.0030)\end{array}$ & $\begin{array}{c}0.0136 * * * \\
(0.0030)\end{array}$ & $\begin{array}{c}0.0143 * * * \\
(0.0029)\end{array}$ & $\begin{array}{c}0.0143 * * * \\
(0.0029)\end{array}$ \\
\hline Employment/Population & $\begin{array}{l}-0.0151 \\
(0.0127)\end{array}$ & $\begin{array}{l}-0.0148 \\
(0.0127)\end{array}$ & $\begin{array}{l}-0.0214^{*} \\
(0.0123)\end{array}$ & $\begin{array}{l}-0.0205^{*} \\
(0.0123)\end{array}$ \\
\hline \% Elderly People & $\begin{array}{l}-0.0652 * \\
(0.0388)\end{array}$ & $\begin{array}{l}-0.0641 * \\
(0.0387)\end{array}$ & $\begin{array}{l}-0.0569 \\
(0.0374)\end{array}$ & $\begin{array}{l}-0.0557 \\
(0.0373)\end{array}$ \\
\hline Candidates Education & & $\begin{array}{c}0.0004 * * * \\
(0.0001)\end{array}$ & $\begin{array}{c}0.0003^{* *} \\
(0.0001)\end{array}$ & $\begin{array}{c}0.0003^{* *} \\
(0.0001)\end{array}$ \\
\hline Candidates' Age & & $\begin{array}{c}0.0001 * * * \\
(0.0000)\end{array}$ & $\begin{array}{c}0.0001^{* *} \\
(0.0000)\end{array}$ & $\begin{array}{c}0.0001 * * \\
(0.0000)\end{array}$ \\
\hline Female Candidates & & $\begin{array}{c}0.0009 \\
(0.0008)\end{array}$ & $\begin{array}{l}-0.0011 \\
(0.0007)\end{array}$ & $\begin{array}{l}-0.0015^{*} \\
(0.0008)\end{array}$ \\
\hline Electoral Margin & & & $\begin{array}{c}-0.0645^{* * *} \\
(0.0021)\end{array}$ & $\begin{array}{c}-0.0610 * * * \\
(0.0022)\end{array}$ \\
\hline No. Candidates & & & & $\begin{array}{c}0.0023 * * * \\
(0.0004)\end{array}$ \\
\hline Constant & $\begin{array}{c}0.8110 * * * \\
(0.0241)\end{array}$ & $\begin{array}{c}0.7980 * * * \\
(0.0244)\end{array}$ & $\begin{array}{c}0.8150 * * * \\
(0.0243)\end{array}$ & $\begin{array}{c}0.8070 * * * \\
(0.0244)\end{array}$ \\
\hline $\begin{array}{l}\text { Observations } \\
\text { R-squared }\end{array}$ & $\begin{array}{c}22,629 \\
0.439\end{array}$ & $\begin{array}{c}22,629 \\
0.440\end{array}$ & $\begin{array}{c}22,629 \\
0.494\end{array}$ & $\begin{array}{c}22,629 \\
0.495\end{array}$ \\
\hline
\end{tabular}

Notes: The dependent variable is voter turnout, as measured by the number of voters on the number of individuals eligible to vote. We control for municipalities fixed effects and for electoral year dummies (not reported) in all the regressions. Standard errors (corrected for heteroskedasticity and clusterized at the municipality level) are reported in parenthesis. The symbols $* * *, * *, *$ indicate that coefficients are statistically significant respectively at the 1,5 , and 10 percent level.

The positive correlation between incumbency and turnout can be related either to the higher availability of information on candidates' expected performance or to the fact that incumbents use their power to obtain electoral support. Before we proceed to investigate this issue, however, we have to take into account the endogeneity issues that may affect our OLS estimates. In fact, estimates shown in Table 2 may be the result of spurious correlation between incumbency and electoral participation: the incumbent's decision to run for election is endogenous and may be affected by unobservable and time variant variables that also affect turnout. In the next section we handle endogeneity problems by using an instrumental variable approach. 


\section{Instrumental Variable Estimates}

To disentangle the causal effect of incumbency on electoral participation we use a Two-Stage-LeastSquare (TSLS) approach, specifying the model presented in the previous section as follows:

[1] Voter_Turnout $_{i t}=\beta_{0}+\beta_{1}$ Incumbent $_{i t}+\beta_{2}$ Political Competition $_{i t}+\beta_{3} X_{i t}+\beta_{4} Z_{i t}+\mu_{t}+\varepsilon_{i t}$

[2] Incumbent $_{i t}=\alpha_{0}+\alpha_{1}$ Binding_Term_Limit $_{i t}+\alpha_{2}$ Political Competition $_{i t}+\alpha_{3} X_{i t}+\alpha_{4} Z_{i t}+\mu_{t}+v_{i t}$

The coefficient $\beta_{1}$ in equation [1] measures the effect of our variable of interest on electoral turnout.

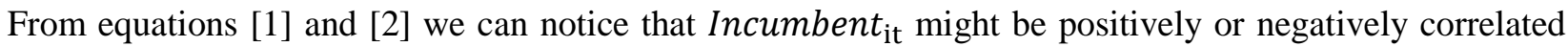
with the error term $\varepsilon_{i t}$, leading to biased estimates in the municipal fixed effects model discussed in the previous section. For instance, some unobservable abilities of the incumbent embedded in the error term of equation [1], such as communicative skills or charisma, may affect both his/her decision to run for election and voters' decision to cast their vote.

To solve this endogeneity problem, we estimate a TSLS model using Binding_Term_Limit ${ }_{\text {it }}$ (a dummy variable taking the value of 1 if the outgoing mayor has already been confirmed for two

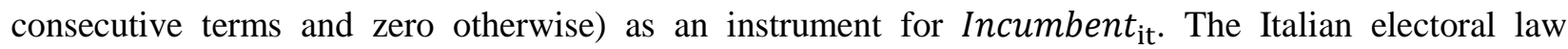
establishes a two mandate term limit and, as a consequence, while incumbent mayors at their first mandate can decide to run or not for re-election (about 36\% of mayors at their first mandate decide to run for reelection), those at their second mandate are excluded from competition. Then, it is possible to have among candidates the outgoing mayor only if he/she has not already spent two consecutive terms in office; in this case the term limit constraint is not binding and our instrument takes the value of 1 , otherwise the term limit is binding and the instrument takes the value of 0 . This implies that Binding_Term_Limit ${ }_{i t}$ is strongly correlated to Incumbent ${ }_{\mathrm{it}}$. On the other hand, Binding_Term_Limit ${ }_{i t}$ is exogenous because we do not expect it to affect through other channels turnout (i.e. it is not included in equation [1]) and, as a consequence, it is not correlated to the error term $\varepsilon_{i t}$.

TSLS estimates are shown in Table 3. Panel B highlights the results from the First Stage regressions. The instrumental variable strongly determines Incumbent ${ }_{i t}$.

Panel A of Table 3 reports the TSLS estimates for the same specifications reported in Table 2. In column (1) and (2), in which we control for municipal and candidates' characteristics respectively, we find that the incumbency status produces a negative and highly statistically significant effect on voter turnout. In particular, having a candidate who held a mayor position in the previous legislature decreases electoral participation by 0.003 percentage points (see column (1)). Similar results are found in column (2) where we add candidates' characteristics. 
As in OLS estimates, once we control for political competition (see columns (3) and (4)), the effect of incumbency on turnout becomes positive. Nevertheless, in TSLS estimates the effect is no longer statistically significant suggesting that once we handle endogeneity issues and control for the indirect effect that incumbency produces on turnout, through the change in electoral competition, no other additional effect is left.

Table 3: TSLS Estimates. Incumbency Effect on Voter Turnout

\begin{tabular}{|c|c|c|c|c|}
\hline & $\begin{array}{c}(1) \\
\text { Voter Turnout }\end{array}$ & $\begin{array}{c}(2) \\
\text { Voter Turnout }\end{array}$ & $\begin{array}{c}(3) \\
\text { Voter Turnout }\end{array}$ & $\begin{array}{c}(4) \\
\text { Voter Turnout }\end{array}$ \\
\hline VARIABLES & $\begin{array}{l}\text { Population } \\
\text { Controls }\end{array}$ & $\begin{array}{l}\text { Population and } \\
\text { Candidates's } \\
\text { Controls }\end{array}$ & $\begin{array}{c}\text { Political Controls: } \\
\text { Electoral Margin }\end{array}$ & $\begin{array}{c}\text { Political Control: } \\
\text { Electoral Margin and } \\
\text { Num. of Candidates }\end{array}$ \\
\hline \multicolumn{5}{|c|}{$\begin{array}{c}\text { Panel A } \\
\text { TSLS } \\
\end{array}$} \\
\hline Incumbent & $\begin{array}{c}-0.0032 * * * \\
(0.0011)\end{array}$ & $\begin{array}{c}-0.0034 * * * \\
(0.0011)\end{array}$ & $\begin{array}{c}0.0002 \\
(0.0011)\end{array}$ & $\begin{array}{c}0.0002 \\
(0.0011)\end{array}$ \\
\hline Population Size/1,000 & $\begin{array}{c}-0.0162 * * * \\
(0.0034)\end{array}$ & $\begin{array}{c}-0.0165^{* * *} \\
(0.0034)\end{array}$ & $\begin{array}{c}-0.0184 * * * \\
(0.0032)\end{array}$ & $\begin{array}{c}-0.0185^{* * *} \\
(0.0032)\end{array}$ \\
\hline Population Size $\wedge 2$ & $\begin{array}{l}0.0004^{* *} \\
(0.0002)\end{array}$ & $\begin{array}{l}0.0004 * * \\
(0.0001)\end{array}$ & $\begin{array}{l}0.0006 * * * \\
(0.0002)\end{array}$ & $\begin{array}{c}0.0006 * * * \\
(0.0002)\end{array}$ \\
\hline Education of Population & $\begin{array}{c}0.0135 * * * \\
(0.0016)\end{array}$ & $\begin{array}{c}0.0136 * * * \\
(0.0016)\end{array}$ & $\begin{array}{c}0.0143 * * * \\
(0.0015)\end{array}$ & $\begin{array}{c}0.0144 * * * \\
(0.0015)\end{array}$ \\
\hline Employment/Population & $\begin{array}{l}-0.0151^{*} \\
(0.0089)\end{array}$ & $\begin{array}{l}-0.0148^{*} \\
(0.0089)\end{array}$ & $\begin{array}{c}-0.0213^{* * *} \\
(0.0085)\end{array}$ & $\begin{array}{c}-0.0204 * * \\
(0.0085)\end{array}$ \\
\hline \% Elderly People & $\begin{array}{c}-0.0648 * * * \\
(0.0229)\end{array}$ & $\begin{array}{c}-0.0636 * * * \\
(0.0229)\end{array}$ & $\begin{array}{c}-0.0566 * * * \\
(0.0218)\end{array}$ & $\begin{array}{c}-0.0554 * * \\
(0.0218)\end{array}$ \\
\hline Candidates' Education & & $\begin{array}{l}0.0005 * * * \\
(0.00013)\end{array}$ & $\begin{array}{c}0.0003 * * \\
(0.0001)\end{array}$ & $\begin{array}{c}0.0003 * * * \\
(0.0001)\end{array}$ \\
\hline Candidates’ Age & & $\begin{array}{c}0.00016 * * * \\
(0.0000)\end{array}$ & $\begin{array}{c}0.0001^{* * *} \\
(0.0000)\end{array}$ & $\begin{array}{c}0.0001^{* * *} \\
(0.0000)\end{array}$ \\
\hline Female Candidates & & $\begin{array}{c}0.0008 \\
(0.0008)\end{array}$ & $\begin{array}{l}-0.0012 \\
(0.0008)\end{array}$ & $\begin{array}{c}-0.0016 * * \\
(0.0008)\end{array}$ \\
\hline Electoral Margin & & & $\begin{array}{c}-0.0640 * * * \\
(0.0016)\end{array}$ & $\begin{array}{c}-0.0606 * * * \\
(0.0017)\end{array}$ \\
\hline No. Candidates & & & & $\begin{array}{c}0.0023 * * * \\
(0.0004)\end{array}$ \\
\hline Observations & 22,629 & 22,629 & 22,629 & 22,629 \\
\hline & & $\begin{array}{l}\text { Panel B } \\
\text { First Stage }\end{array}$ & & \\
\hline VARIABLES & Incumbent & Incumbent & Incumbent & Incumbent \\
\hline Binding Term Limit & $\begin{array}{c}-0.7352 * * * \\
(0.007)\end{array}$ & $\begin{array}{c}-0.7267 * * * \\
(0.007)\end{array}$ & $\begin{array}{c}-0.7199 * * * \\
(0.007)\end{array}$ & $\begin{array}{c}-0.7199 * * * \\
(0.007)\end{array}$ \\
\hline $\begin{array}{l}\text { First Stage F-Stat } \\
\text { (p-value) }\end{array}$ & $\begin{array}{l}9,353.02 \\
(0.0000)\end{array}$ & $\begin{array}{l}9,215.96 \\
(0.0000)\end{array}$ & $\begin{array}{l}9,055.40 \\
(0.0000)\end{array}$ & $\begin{array}{l}9,055.37 \\
(0.0000)\end{array}$ \\
\hline Adj- R squared & 0.54 & 0.55 & 0.55 & 0.55 \\
\hline
\end{tabular}

Notes: The dependent variable is voter turnout, as measured by the number of voters on the number of individuals eligible to vote. We control for municipalities fixed effects and for electoral year dummies (not reported) in all the regressions. Standard errors (corrected for heteroskedasticity and clusterized at the municipality level) are reported in parenthesis. The symbols $* * *, * *, *$ indicate that coefficients are statistically significant respectively at the 1,5 , and 10 percent level.

The channels through which incumbency may affect turnout may work dissimilarly in different parts of Italy. We are indeed considering a country that is very heterogeneous in terms of economic and 
social condition, with the northern part being richer and endowed with higher social capital compared to the South. To investigate whether the relationship between incumbency and turnout is heterogeneous in the two parts of the country we have run separate regressions ${ }^{13}$ for municipalities located in the CenterSouth and in the North of Italy. Results are reported in Table 4. As shown in columns (1) and (2), it emerges a positive and statistically significant effect, at the 5 percent level, for the South (column 1), while the effect is negative but not statistically significant for the North (column 2).

Table 4: TSLS Estimates. Incumbency Effect on Voter Turnout: North vs South

\begin{tabular}{|c|c|c|c|c|}
\hline & $\begin{array}{c}(1) \\
\text { Voter Turnout }\end{array}$ & $\begin{array}{c}\text { (2) } \\
\text { Voter Turnout }\end{array}$ & $\begin{array}{c}\text { (3) } \\
\text { Voter Turnout }\end{array}$ & $\begin{array}{c}(4) \\
\text { Voter Turnout }\end{array}$ \\
\hline VARIABLES & Center-South & North & $\begin{array}{c}\text { South - Low Social } \\
\text { Capital }\end{array}$ & $\begin{array}{c}\text { South - High Social } \\
\text { Capital }\end{array}$ \\
\hline & & $\begin{array}{c}\text { Panel A } \\
\text { TSLS }\end{array}$ & & \\
\hline Incumbent & $\begin{array}{c}0.0036^{* *} \\
(0.0018)\end{array}$ & $\begin{array}{l}-0.0006 \\
(0.0012)\end{array}$ & $\begin{array}{c}0.0049 * * \\
(0.0028)\end{array}$ & $\begin{array}{c}0.0018 \\
(0.0023)\end{array}$ \\
\hline Population/1,000 & $\begin{array}{c}0.0088 \\
(0.0058)\end{array}$ & $\begin{array}{c}-0.0171 * * * \\
(0.0036)\end{array}$ & $\begin{array}{c}0.0260 * * * \\
(0.0082)\end{array}$ & $\begin{array}{c}0.0489 * * * \\
(0.0073)\end{array}$ \\
\hline Population Size ${ }^{\wedge} 2$ & $\begin{array}{l}-0.0005^{*} \\
(0.0003)\end{array}$ & $\begin{array}{c}0.0004 * * \\
(0.0002)\end{array}$ & $\begin{array}{c}-0.0011^{* *} \\
(0.0004)\end{array}$ & $\begin{array}{c}-0.0023^{* * *} \\
(0.0004)\end{array}$ \\
\hline Education of Population & $\begin{array}{l}-0.0034 \\
(0.0025)\end{array}$ & $\begin{array}{l}-0.0020 \\
(0.0019)\end{array}$ & $\begin{array}{l}0.0070 * \\
(0.0040)\end{array}$ & $\begin{array}{l}-0.0047 \\
(0.0035)\end{array}$ \\
\hline Employment/Population & $\begin{array}{c}0.0545 * * * \\
(0.0167)\end{array}$ & $\begin{array}{l}-0.0152 \\
(0.0091)\end{array}$ & $\begin{array}{c}0.0687 * * \\
(0.0275)\end{array}$ & $\begin{array}{c}0.0700 * * * \\
(0.0214)\end{array}$ \\
\hline \% Elderly People & $\begin{array}{c}-0.4801 * * * \\
(0.0407)\end{array}$ & $\begin{array}{l}-0.0327 \\
(0.0246)\end{array}$ & $\begin{array}{c}-0.4461 * * * \\
(0.0567)\end{array}$ & $\begin{array}{c}-0.5238 * * * \\
(0.0599)\end{array}$ \\
\hline Candidates' Education & $\begin{array}{l}0.0006 * * * \\
(0.0002)\end{array}$ & $\begin{array}{l}0.0002 * \\
(0.0001)\end{array}$ & $\begin{array}{l}0.0014 * * * \\
(0.0004)\end{array}$ & $\begin{array}{c}0.0001 \\
(0.0003)\end{array}$ \\
\hline Candidates's Age & $\begin{array}{c}0.0001 \\
(0.0000)\end{array}$ & $\begin{array}{l}0.0009 * \\
(0.0005)\end{array}$ & $\begin{array}{l}0.0002^{* *} \\
(0.0001)\end{array}$ & $\begin{array}{l}-0.0001 \\
(0.0001)\end{array}$ \\
\hline Female Candidates & $\begin{array}{l}-0.0013 \\
(0.0015)\end{array}$ & $\begin{array}{l}-0.0011 \\
(0.0008)\end{array}$ & $\begin{array}{l}-0.0039 \\
(0.0025)\end{array}$ & $\begin{array}{c}0.0006 \\
(0.0018)\end{array}$ \\
\hline Electoral Margin & $\begin{array}{c}-0.0809 * * * \\
(0.0031)\end{array}$ & $\begin{array}{c}-0.0524 * * * \\
(0.0018)\end{array}$ & $\begin{array}{c}-0.0757 * * * \\
(0.0050)\end{array}$ & $\begin{array}{c}-0.0788 * * * \\
(0.0041)\end{array}$ \\
\hline No. Candidates & $\begin{array}{l}0.0016 * * \\
(0.0007)\end{array}$ & $\begin{array}{c}0.0033^{* * *} \\
(0.0005)\end{array}$ & $\begin{array}{l}0.0029 * * \\
(0.0012)\end{array}$ & $\begin{array}{l}-0.0005 \\
(0.0009)\end{array}$ \\
\hline Observations & 8,316 & $\begin{array}{c}14,313 \\
\text { Panel B } \\
\text { First Stage }\end{array}$ & 4,025 & 4,022 \\
\hline VARIABLES & Incumbent & Incumbent & Incumbent & Incumbent \\
\hline Binding Term Limit & $\begin{array}{c}-0.7007 * * * \\
(0.0127)\end{array}$ & $\begin{array}{c}-0.7309 * * * \\
(0.0094)\end{array}$ & $\begin{array}{c}-0.6901 * * * \\
(0.0178)\end{array}$ & $\begin{array}{c}-0.7198 * * * \\
(0.0184)\end{array}$ \\
\hline $\begin{array}{l}\text { First Stage F-Stat } \\
\text { (p-value) }\end{array}$ & $\begin{array}{l}3,024.94 \\
(0.0000)\end{array}$ & $\begin{array}{l}6,015.89 \\
(0.0000)\end{array}$ & $\begin{array}{l}1,495.97 \\
(0.0000)\end{array}$ & $\begin{array}{l}1,528.70 \\
(0.0000)\end{array}$ \\
\hline Adj- R squared & 0.52 & 0.57 & 0.52 & 0.52 \\
\hline
\end{tabular}

Notes: The dependent variable is voter turnout, as measured by the number of voters on the number of individuals eligible to vote. We control for municipalities fixed effects and for electoral year dummies (not reported) in all the regressions. Standard errors (corrected for heteroskedasticity and clusterized at the municipality level) are reported in parenthesis. The symbols $* * *, * *, *$ indicate that coefficients are statistically significant respectively at the 1,5 , and 10 percent level.

\footnotetext{
${ }^{13}$ The regressions are the same as that reported in column (4) of Table 3, in which we consider the full set of controls.
} 
The positive effect of incumbency on turnout we find for elections held in the South of Italy can be related either to the improvement in the information available to voters on candidates' expected performance or to the fact that incumbents use their power to obtain electoral support. In the first case, the increase in turnout is due to the fact that even if not all the mayors running for re-election performed well in the past, knowing their performance allows electors to be more informed and enables them to express a preference. In the second case, instead, the increase in turnout is mainly related to the clientelistic relationships established by the incumbent candidates, which ensure political support in exchange of benefits.

Both these channels are possible, but we would expect the first channel to work also in the northern part on the country. On the other hand, clientelistic relationships are more likely to emerge in the South. As argued by Putman (1993), the emergence of "exchange votes" is more likely in areas characterized by poor economic conditions and weak social capital. In these areas contracts with government officials tend to overwhelmingly involve requests for jobs and patronage. In addition, even if problems related to clientelism and corruption at local level are mitigated by the fact that citizens are able to monitor politicians' behavior better than a distant central authority, ${ }^{14}$ when social capital is low, citizens tend to free ride avoiding to protest against government malfeasance and public officials can easily indulge in inefficient policies aimed at increasing electoral support.

The main difference in social capital endowment in Italy is between North and South. However, there are also differences within each area. Then, we consider a number of social capital indicators (blood donation ${ }^{15}$, trust level ${ }^{16}$, tax evasion ${ }^{17}$ ) and split the North and the South samples at the median values of these indicators. In Table 4, columns (3) and (4), we report results obtained when we consider as a measure of social capital an indicator of tax compliance based on television licenses (the number of television licenses on the number of households in each municipality). We think that compliance for this particular tax is a good indicator of social capital since the payment of television licenses is levied on all households who own a television (99\% in Italy with little regional variation ${ }^{18}$ ), but it is weakly enforced. In addition this indicator has the advantage of being available at municipal level, while the other indicators based on trust and donations are at regional and provincial level respectively. In the South about $65 \%$ of households pay the license (with a standard deviation of 11.82), while in the North this percentage rises to $75 \%$ (with a standard deviation of 10.5).

When we split the sample of northern and southern municipalities above and below the median value of the tax evasion indicator in the area, we find that in the North the relationship between

\footnotetext{
${ }^{14}$ See Conning and Kevane (1999), Jimenez and Sawada (1999) and Mookherjee (2001). For instance, large-scale bribery will be more noticeable by local residents who have to pay these bribes and live in close proximity to local government officials (Bardhan and Mookherjee, 2005).

${ }^{15}$ The number of blood bags (each bag contains 16 ounces of blood) per million inhabitants in each province collected by AVIS.

${ }^{16}$ According to the World Value Social Survey (at the regional level) in year 1990 and 1999.

${ }^{17}$ We use the number of TV licenses on the number of household in each municipality (RAI abbonamenti).

${ }^{18}$ Istat, 2005, "Aspetti della vita quotidiana".
} 
incumbency and turnout is not statistically significant neither in municipalities with a level of social capital above the median nor in municipalities with a level of social capital below the median (results not reported). On the contrary, for the southern part of the country we find that the relationship is positive and statistically significant at the 5 percent level only in those municipalities characterized by a level of social capital below the median in the area (65.76\%) (see columns (3) and (4) of Table 4).

The same results are found when we measure social capital using the indicators based on trust and blood donation (results not reported and available upon request). Again, while in the northern part of the country incumbency does not affect turnout, in the South the effect is positive for those municipalities characterized by particularly low levels of social capital.

We take these results as suggestive of the fact that in municipalities characterized by very low levels of social capital, incumbent politicians use their power and resources to establish clienteles and to offer benefits of different kind in exchange of electoral support. We cannot exclude other channels, such as the electors' desire to punish incumbent politicians, who may have poorly performed in low social capital areas, and to vote in favor of a new candidate. However, in this case we would also expect a smaller incumbency advantage in areas endowed with lower social capital. To get some evidence on this issue we have used our data to analyze whether the incumbency advantage is related to social capital. At this aim we have regressed the percentage of votes obtained by each candidate on whether a candidate is an incumbent, controlling for gender, age and education differences among opponents, for municipal fixed effects and municipal characteristics. ${ }^{19}$ We find a slightly higher incumbency advantage $(+12.20$ percent $)$ in southern municipalities characterized by low levels of social capital compared to other southern municipalities endowed with higher levels of social capital (+11.67 percent) (results not reported and available upon request). ${ }^{20}$ This evidence, even if only suggestive (as we are not handling endogeneity problems arising in this type of estimates), supports the idea that the positive relationship between turnout and incumbency in southern municipalities characterized by low social capital is the result of patronage practices.

\section{Concluding Remarks}

Having an incumbent among candidates at the electoral race can affect turnout through both indirect and direct channels. The incumbent candidate, due to the incumbency advantage (disadvantage), can reduce (increase) the degree of political competition and, as a consequence, voters might be less (more) inclined to participate to the polls. In addition, since elections in which one or more incumbents run for re-election

\footnotetext{
${ }^{19}$ To make easier the interpretation of results, we restrict our analysis to only those elections in which two candidates compete.

${ }^{20}$ We also find that the incumbency advantage diminishes with social capital both in the North and in the South of the country.
} 
are typically characterized by a higher availability of information, electors may take advantage of this information and be inclined to express their vote (Grofman et al., 1995; Keele, 2007).

In this paper, by using data on electoral results of Italian municipal elections over the period 19932011, we have tried to shed some light on these effects. We have firstly estimated an OLS model. Controlling for municipal fixed effect and a number of municipal and candidates' characteristics, we find that having a candidate who performed the mayor charge in the previous legislature produces a negative effect on turnout. However, once we control for the degree of political competition at the electoral race the effect of incumbency on turnout changes sign and becomes positive and statistically significant.

To handle endogeneity problems arising from the fact that the incumbent decision to run for reelection may be affected by unobservable and time variant variables that also affect turnout, we have used an instrumental variable approach, instrumenting the incumbency status with the mayor term-limit, imposed by the Italian law. This instrument is strongly correlated to the presence of the incumbent mayor among candidates and should not directly affect turnout.

TSLS estimation results confirm OLS estimates and show a negative and statistically significant effect of incumbency on electoral participation. This effect is again driven by the reduction that incumbency produces on electoral competition. When we control for the "closeness" of the electoral race, we find a positive but (in contrast to OLS estimates) not statistically significant effect. There is also evidence, however, that the impact of incumbency is heterogeneous across geographical areas. When we distinguish between municipalities located in the North and in the South of Italy, we find that incumbency does not affect turnout in northern municipalities, but it produces a positive and statistically significant effect in the South, in particular in those municipalities endowed with low levels of social capital.

As we do not expect this positive effect to be related to a better performance of incumbent politicians working in these areas, or to a greater desire of citizens to punish their bad past performance (the incumbency advantage in municipalities endowed with low social capital is higher), we speculate that it may be related to the fact that the incumbent candidate, taking advantage of the low social capital, uses his/her power and resources to obtain votes in change of private benefits.

\section{References}

Alesina, A., and Tabellini, G., (2008), "Bureaucrats or Politicians? Part II: Multiple Policy Tasks”, Journal of Public Economics, 92, 426-447.

Ansolabehere, S., Snyder, J. M., and Stewart, C., (2000), “Old Voters, New Voters, and the Personal Vote: Using Redistricting to Measure the Incumbency Advantage”, American Journal of Political Science, 44, 17-34.

Bardhan, P., and Mookherjee, D., (2005), "Decentralizing Antipoverty Program Delivery in Developing Countries”, Journal of Public Economics, 89(4), 675-704.

Besley, T., (2005), "Principled Agents? The Political Economy of Good Government”, Oxford: Oxford University Press. 
Butler, D.M., (2009), “A Regression Discontinuity Design Analysis of the Incumbency Advantage and Tenure in the U.S. House”, Electoral Studies, 28,123-8.

Conning, J., Kevane, M., (1999), “Community Based Targeting Mechanisms for Social Safety Nets”, Mimeo, Department of Economics, Williams College.

De Paola, M., Lombardo, R., and Scoppa, V., (2010), “Can Gender Quotas Break Down Negative Stereotypes? Evidence from Changes in Electoral Rules”, Journal of Public Economics 94, 344-353.

De Paola, M., and Scoppa, V., (2011), "Political Competition and Politician Quality: Evidence from Italian Municipalities”, Public Choice, 148(3-4), 547-559.

De Paola, M., and Scoppa, V., (2012), "The Causal Impact of Closeness on Electoral Participation Exploiting the Italian Dual Ballot System”, Working Paper.

De Paola, M., Scoppa, V., and De Benedetto, M.A., (2013), "The Impact of Gender Quotas on Electoral Participation: Evidence from Italian Municipalities”, Working Paper.

Fauvelle-Aymar, C., and Francois, A., (2006), "The Impact of Closeness on Turnout: An Empirical Relation Based on a Study of a Two-round Ballot”, Public Choice, 127, 469-491.

Ferejohn, J., (1986), “Incumbent Performance and Electoral Control”, Public Choice, 50, 5-25.

Golebiowska, E.A., (2001), “Group Stereotypes and Political Evaluation”, American Politics Research, 29, 535-565.

Grofman, B., Owen, G., and Collet, C., (1995), "Rethinking the Partisan Effects of Higher Turnout: So What's the Question?”, Public Choice, 99, 357-376.

Hainmueller, J., and Kern, H.L., (2008), "Incumbency as a Source of Spillover Effects in Mixed Electoral Systems: Evidence from a Regression-Discontinuity Design”, Electoral Studies, 27, 213-227.

Hansford, T., and Gomez, B., (2010), "Estimating the Electoral Effects of Voter Turnout", American Political Science Review, 104(2).

Jimenez, E., and Sawada, Y., (1999), "Do Community-Managed Schools Work? An Evaluation of el Salvador's EDUCO Program”, World Bank Economic Review, 13 (3), 415- 442.

Kahn, K.F., (1993), "Incumbency and the News Media in U.S. Senate Elections: An Experimental Investigation”, Political Research Quarterly, 46 (4), 715-740.

Keele, L., (2007), "Social Capital and the Dynamics of Trust in Government”, American Journal of Political Science, 51, 241-254.

Knack, S., (2002), "Social Capital and the Quality of Government: Evidence from the States”, American journal of Political Science, 46, 772-785.

Linden, L., (2004), “Are Incumbents Really Advantaged? The Preference for Non-Incumbents in Indian National Elections”, Working Paper.

McDermott, M.L., (1997), "Voting Cues in Low-Information Elections”, American Journal of Political Science, 41(1), 270-283.

McDermott, M.L, (2005), "Candidate Occupations and Voter Information Shortcuts", The Journal of Politics, 67 (1).

Miguel, E., and Zahidi, F., (2004), "Do Politicians Reward their Supporters? Public Spending and Incumbency Advantage”, Working Paper.

Mookherjee, D., (2001), "Combating the Crisis in Government Accountability: A Review of Recent International Experience”, Working Paper. Institute for Economic Development, Boston University.

Mueller, D.C., (2003), “Public Choice III”, Cambridge: Cambridge University Press.

Nannicini, T., Stella, A., Tabellini, G., and Troiano, U., (2013), "Social Capital and Political Accountability", American Economic Journal: Economic Policy, 5, 222-250.

Persson, T., and Tabellini, G., (2000), "Political Economics”, Cambridge, MA: MIT Press.

Putnam, R., (1993), “Making Democracy Work: Civic Traditions in Modern Italy”, Princeton: Princeton University Press.

Sigelman, C.K., Sigelman, L., Walkosz, B.J., and Nitz, M., (1995), "Black Candidates, White voters: Understanding Racial Bias in Political Perceptions”, American Journal of Political Science, 39(1), 243-265.

Simonovits, G., (2011), “Closeness and Turnout in Runoff Elections: Evidence from Hungary”, mimeo.

Titiunik, R., (2009), "Incumbency Advantage in Brazil: Evidence from Municipal Mayor Elections”, Working Paper.

Trounstine, J., (2013), "Turnout and Incumbency in Local Elections", Urban Affairs Review, 49(2). 
Uppal, Y., (2009), “The Disadvantaged Incumbents: Estimating Incumbency Effects in Indian State Legislatures”, Public Choice, 138, 9-27.

Washington, E., (2006), "How Black Candidates Affect Voter Turnout”, Yale Working Papers on Economic Applications and Policy.

Wolf, A.B., (2011), "The Effect of Candidate Gender on Voter Registration and Turnout”, Working Paper. 